\title{
Geodesy and Contemporary Strain in the Yucca Mountain Region, Nevada
}

\section{U.S. GEOLOGICAL SURVEY}

Open-File Report 97-383

Prepared in cooperation with the NEVADA OPERATIONS OFFICE U.S. DEPARTMENT OF ENERGY (Interagency Agreement DE-Al08-92NV10874)

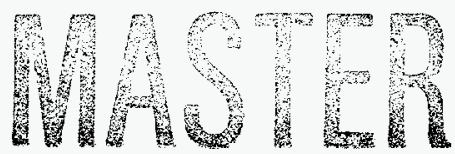

\section{DISCLAIMER}

This report was prepared as an account of work sponsored by an agency of the United States Government. Neither the United States Government nor any agency thereof, nor any of their employees, makes any warranty, express or implied, or assumes any legal liability or responsibility for the accuracy, completeness, or usefulness of any information, apparatus, product, or process disclosed, or represents that its use would not infringe privately owned rights. Reference herein to any specific commercial product, process, or service by trade name, trademark, manufacturer, or otherwise does not necessarily constitute or imply its endorsement, recommendation, or favoring by the United States Government or any agency thereof. The views and opinions of authors expressed herein do not necessarily state or reflect those of the United States Government or any agency thereof.
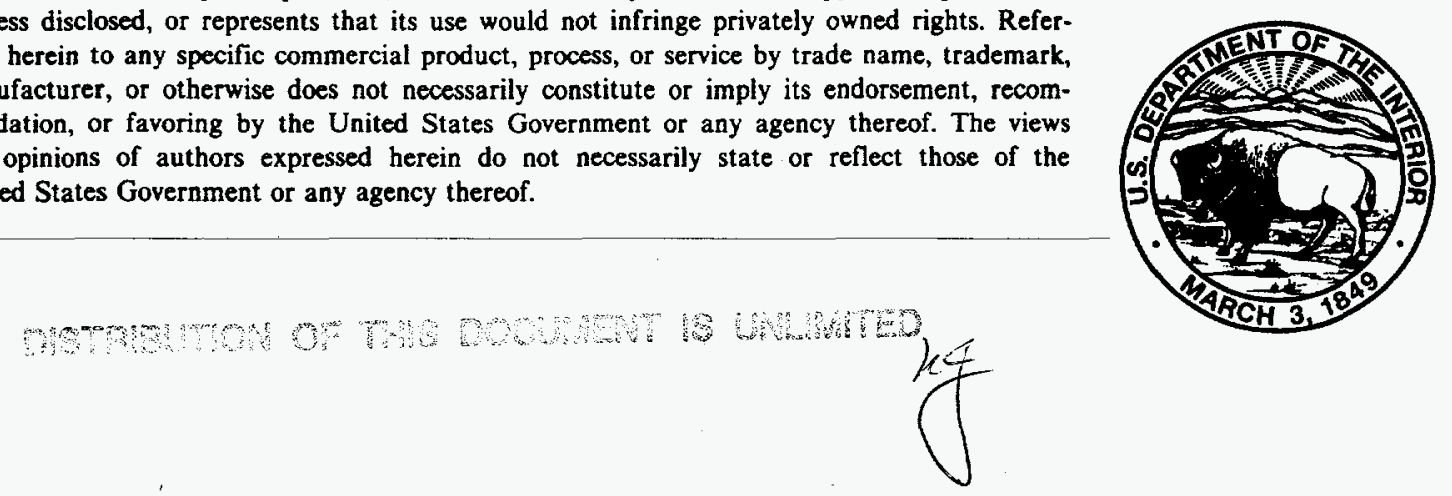


\section{Geodesy and Contemporary Strain in the Yucca Mountain Region, Nevada}

By W.R. Keefer, J.A. Coe, S.K. Pezzopane, and W. Clay Hunter

U.S. GEOLOGICAL SURVEY

Open-File Report 97-383

Prepared in cooperation with the

NEVADA OPERATIONS OFFICE

U.S. DEPARTMENT OF ENERGY

(Interagency Agreement DE-Al08-92NV10874)

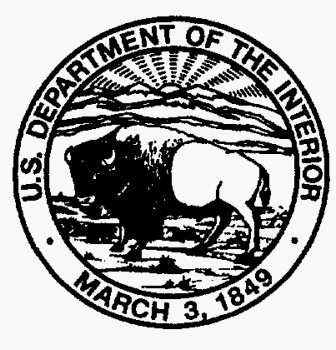




\title{
U.S. DEPARTMENT OF THE INTERIOR \\ BRUCE BABBITT, Secretary
}

\author{
U.S. GEOLOGICAL SURVEY \\ Gordon P. Eaton, Director
}

The use of firm, trade, and brand names in this report is for identification purposes only and does not constitute endorsement by the U.S. Geological Survey.

For additional information write to:

Chief, Earth Science Investigations Program Yucca Mountain Project Branch

U.S. Geological Survey

Box 25046, Mail Stop 421

Denver Federal Center

Denver, CO 80225-0046
Copies of this report can be purchased from:

U.S. Geological Survey

Information Services

Box 25286

Federal Center

Denver, CO 80225 


\section{DISCLAMMER}

Portions of this document may be illegible in electronic image products. Images are produced from the best available original document. 


\section{CONTENTS}

Abstract ntroduction
Background and Purpose
Geologic Setting
Geodetic Leveling .
Trilateration - Global Positioning System Long Baseline Interferometry
Conclusions
References

\section{ILLUSTRATIONS}

1. Map showing locations of the southwestern Nevada volcanic field and selected volcanic and physiographic features of the Yucca Mountain region, Nevada

2. Index map of Yucca Mountain (dashed outline) and vicinity, Nevada, showing boundaries of areas commonly referred to in site-characterization studies and reports....

3. Index map showing the location of first-order level lines in the vicinity of Yucca Mountain, Nevada

4. Profile plots showing data from surveys of level line across Yucca Mountain, Nevada, during the period 1983 to 1993

5. Profiles showing terrain elevations and height changes with respect to the 1907 baseline between Beatty and Las Vegas, Nevada

6. Map showing the trilateration network near Yucca Mountain, Nevada

7. Index map showing location of relevant and potentially relevant faults capable of generating average median and 84th-percentile peak accelerations that equal or exceed $0.1 \mathrm{~g}$ at the potential waste repository at Yucca Mountain, Nevada

\section{TABLES}

1. Major stratigraphic units in the Late Cenozoic volcanic rock sequence of the Yucca Mountain area, Nevada ........

CONVERSION FACTORS, VERTICAL DATUM, AND ABBREVIATIONS

\begin{tabular}{rll}
\hline Multiply & By & To obtain \\
\hline centimeter $(\mathrm{cm})$ & 0.3937 & inch \\
meter $(\mathrm{m})$ & 3.281 & foot \\
kilometer $(\mathrm{km})$ & 0.6214 & mile \\
millimeter $(\mathrm{mm})$ & 0.03937 & inch \\
square kilometer $\left(\mathrm{km}^{2}\right)$ & 0.3861 & square mile \\
\hline
\end{tabular}

\footnotetext{
ADDITIONAL ABBREVIATIONS

g gravitational acceleration

$\mathrm{mm} / \mathrm{yr} \quad$ millimeter per year

$\mathrm{Ma} \quad$ Millions of years

VLBI Very Long Baseline Interferometry
} 


\title{
Geodesy and Contemporary Strain in the Yucca Mountain Region, Nevada
}

\author{
By W.R. Keefer, J.A. Coe, S.K. Pezzopane, and W. Clay Hunter
}

\section{Abstract}

Geodetic surveys provide important information for estimating recent ground movement in support of seismotectonic investigations of the potential nuclear-waste storage site at Yucca Mountain, Nevada. Resurveys of established level lines document up to 22 millimeters of local subsidence related to the 1992 Little Skull Mountain earthquake, which is consistent with seismic data that show normalslip rupture and with data from a regional trilateration network. Comparison of more recent surveys with a level line first established in 1907 suggests 3 to 13 centimeters of subsidence in the Crater Flat-Yucca Mountain structural depression that coincides with the Bare Mountain fault; small uplifts also were recorded near normal faults at Yucca Mountain. No significant deformation was recorded by a trilateration network over a 10 -year period, except for coseismic deformation associated with the Little Skull Mountain earthquake, but meaningful results are limited by the short temporal period of that data set and the small rate of movement. Very long baseline interferometry that is capable of measuring direction and rates of deformation is likewise limited by a short history of observation, but rates of deformation between 8 and 13 millimeters per year across the Basin and Range province are indicated by the available data.

\section{INTRODUCTION}

Since the late 1970s, Yucca Mountain, in southwestern Nevada, has been investigated by the U.S. Department of Energy in cooperation with agencies including the U.S. Geological Survey, as a potential national geologic repository for the storage of high-level radioactive wastes. As part of a broad interdisciplinary program which is designed to evaluate comprehensively the suitability of the Yucca Mountain site (U.S. Department of Energy, 1988), a series of specific studies that bear on the structural geology, tectonic evolution, and seismicity of the Yucca Mountain region (fig. 1), including the one discussed herein, was undertaken in the mid-1980s to analyze ground motion and fault-displacement hazards that may affect repository design and performance. Site-characterization efforts generally have focused on a specific site area (fig. 2) in which mapping and related studies were conducted in greater detail than in surrounding areas. A fan-shaped "controlled area" of some 90 square kilometers (fig. 2) results from regulatory requirements (Title 10 of the Code of Federal Regulations, 10CFR60 and 10CFR960) and surrounds a "potential repository site" that represents the upward projection of the boundary of the proposed underground storage facilities.

\section{Background and Purpose}

This report is one of a series that describes results and presents interpretations of available information on the tectonics and seismicity of Yucca Mountain, including those geologic elements (structural, stratigraphic, volcanic, and geomorphic) that contribute to the makeup and tectonic evolution of 


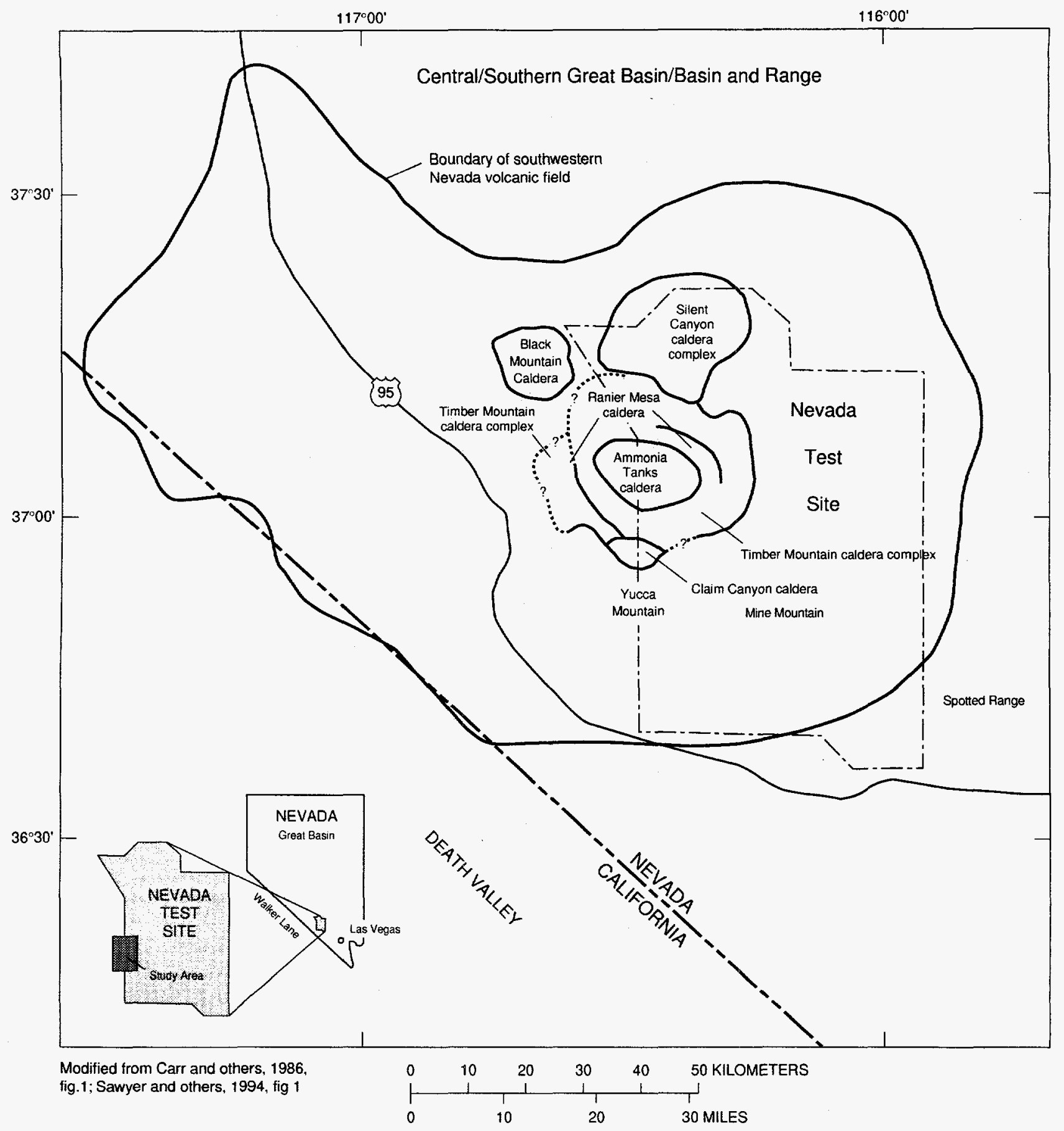

Figure 1. Locations of the southwestern Nevada volcanic field and selected volcanic and physiographic features of the Yucca Mountain region. The study area is also shown as

"site area" on figure 2. Modified from Carr and others, 1986, and Sawyer and others, 1994. 


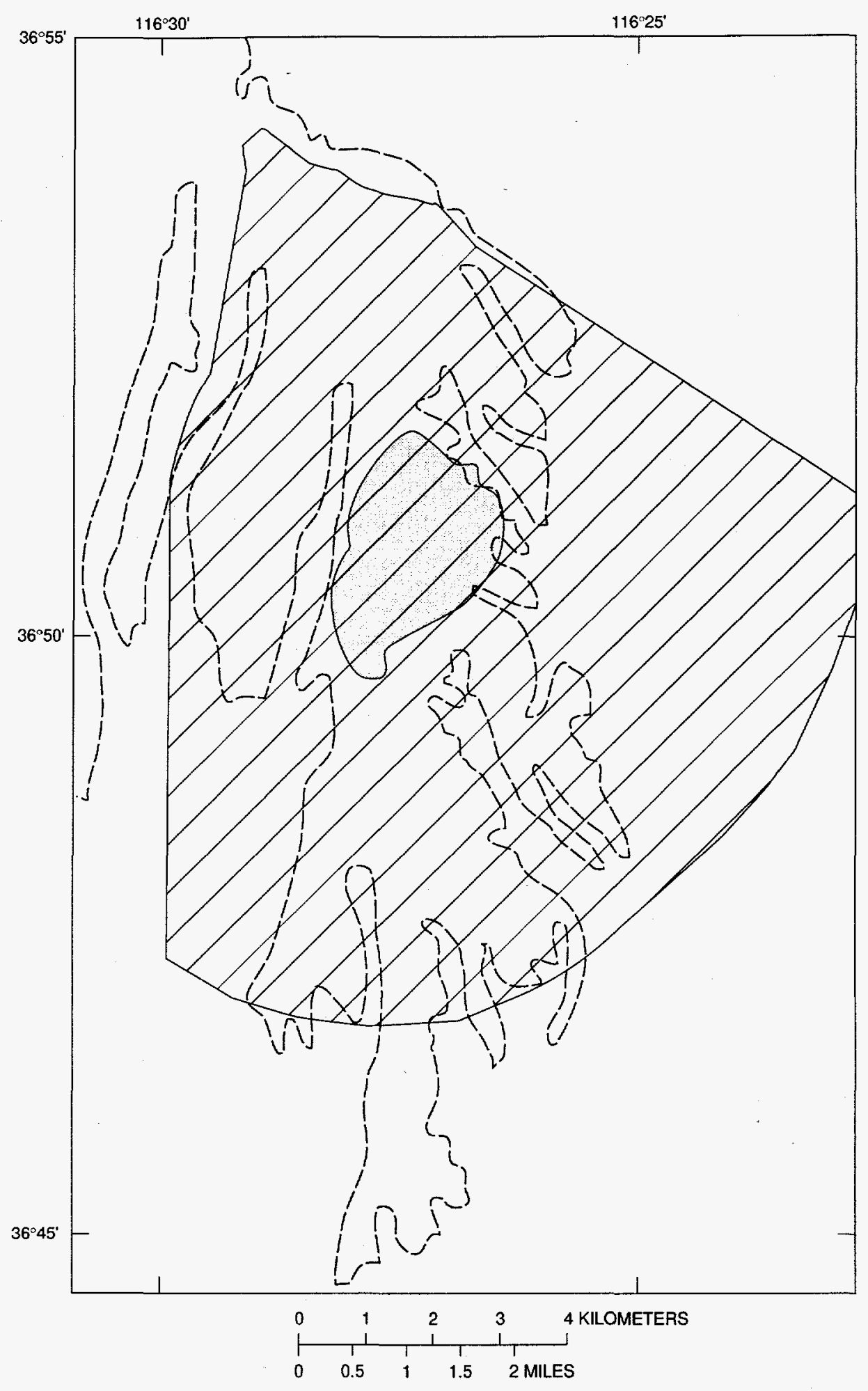

Figure 2. Index map of Yucca Mountain (dashed outline) and vicinity, Nevada, showing boundaries of areas commonly referred to in site-characterization studies and reports. Outside boundaries of the map define the "site area" (same area as shown in figure 1) encompassing most of the significant geologic features being mapped and studied in detail at or in close proximity to Yucca Mountain. The extent of the potential repository (upward projection of the boundaries of the underground facility) is shown by the shaded area, and the extent of the controlled area is marked by diagonal lines. Modified from Rautman and others, 1987. 
Yucca Mountain, neighboring ranges and bounding basins, the proximal fault zones that distinguish the structural pattern of Yucca Mountain and surrounding areas (typical of the southern Great Basin), the foci of seismic events, and adjacent volcanic fields. Of most interest to the site-characterization program are features that generally occur within $100 \mathrm{~km}$ of Yucca Mountain (fig. 1).

Subjects covered in these reports were discussed in detail in the Yucca Mountain Site Characterization Plan (SCP; U.S. Department of Energy, 1988). Techniques and methods of study supporting specifically defined objectives are described in widely reviewed study plans for individual investigations. The scope of these structural, seismic, and tectonic investigations covered (1) identification and characterization of faults, both at Yucca Mountain and in surrounding areas, with emphasis on faults with demonstrable Quaternary activity; (2) distribution and geochronology of Quaternary deposits, data that record paleoseismicity and lead to calculations of amounts, rates, and recurrence intervals of Quaternary fault displacements; (3) seismicity in the southern Great Basin and earthquake magnitude and recurrence rates at Yucca Mountain; (4) location and characterization of relevant earthquake sources; and (5) development of tectonic models.

Regulations embodied in the Nuclear Waste Policy Act of 1982 and the Code of Federal Regulations (10CFR60 and 10 CFR960) require evaluation of natural phenomena that might compromise the design, safety, and performance of a geologic repository, including potentially adverse conditions such as landslides, subsidence, volcanic eruptions, changes in climatic conditions and water-table levels, structural deformation (especially during the Quaternary), and seismic activity and frequency. Specific information needs include identification of relevant earthquake sources, estimation of peak acceleration, amounts of ground motion and other ground-motion characteristics, preparation of data sets for seismic-source evaluation, consideration of historical seismicity, characterization of Quaternary faults within $100 \mathrm{~km}$ of Yucca Mountain, mapping and analysis of fault zones, determination of the extent of detachment faulting in the region, and geodetic leveling to determine contemporary deformation. The combined information provides the basis for the development of tectonic models that may contribute to a better and more comprehensive understanding of the processes that could impact repository design and performance.

Rates of tectonic processes during recent, historical, and pre-historical Quaternary times-the three separate time periods of particular significance to Yucca Mountain site characterization-are determined from contemporary observations, recorded history, and geochronological data on Quaternary deposits and fault movements, respectively. This report summarizes results of various geodetic surveys that have been conducted in the Yucca Mountain area and the surrounding region to provide quantitative data on crustal movements and strain accumulations during the most recent of these time periods.

\section{Geologic Setting}

Yucca Mountain, which is located near the western boundary of the Nevada Test Site in southwestern Nevada about $140 \mathrm{~km}$ northwest of Las Vegas, lies in the north-central part of the Basin and Range physiographic province and consists of a series of rugged north-trending fault-block ridges composed of volcanic rocks that generally have an eastward tilt of $5^{\circ}$ to $10^{\circ}$ (Scott and Bonk, 1984). The potential site area is situated on the southern flank of the Miocene southwestern Nevada volcanic field (Byers and others, 1976; fig. 1). A thick section of Tertiary volcanic rocks (table 1) overlies Paleozoic sedimentary strata in the Yucca Mountain region (Byers and others, 1976), with units of the 12.8 to $12.7 \mathrm{Ma}$ Paintbrush Group (Sawyer and others, 1994) forming most exposures (Christiansen and Lipman, 1965; Scott and Bonk, 1984). Two voluminous densely welded ash-flow tuffs of the Paintbrush Group underlie Yucca Mountain (the Tiva Canyon and Topopah Spring Tuffs), separated by a much thinner interval of mostly nonwelded pyroclastic rocks (Buesch and others, 1996); the tuffaceous rocks are greater than $3,000 \mathrm{~m}$ thick in some places (Snyder and Carr, 1984). High-angle faults locally exhibit displacements of several hundred meters (Carr, 1984; Scott and Bonk, 1984). The geometry of these normal faults and of northweststriking strike-slip faults controls most of the topography and drainage at Yucca Mountain. The right-lateral strike-slip faults have been linked to the Walker Lane (Carr, 1984), a large structural zone (fig. 1) that parallels the southwestern border of Nevada. Extensional faulting is present between the 
Paleozoic and Tertiary rocks (Carr and Monsen, 1988) at the northern end of Bare Mountain (fig. 1), an uplifted fault block consisting of complexly deformed sedimentary and metasedimentary rocks of Paleozoic and Precambrian age. Bare Mountain bounds the western side of Crater Flat, a $200-\mathrm{km}^{2}$ depositional basin adjacent to Yucca Mountain (fig. 3). This alluvial flat is the most strongly extended and most deeply subsided part of the Crater Flat structural basin, a graben-like domain that also includes Yucca Mountain (Fridrich, in press).

Table 1. Major stratigraphic units in the Late Cenozoic volcanic rock sequence of the Yucca Mountain area, Nevada. Ages are given in millions of years (Ma). Modified from Sawyer and others (1994) and Buesch and others (1996).

\begin{tabular}{ll}
\multicolumn{1}{c}{ Unit } & \multicolumn{1}{c}{$\begin{array}{l}\text { Age } \\
\text { (Ma) }\end{array}$} \\
\hline Timber Mountain Group & 11.45 \\
Ammonia Tanks Tuff & 11.6 \\
Rainier Mesa Tuff & 12.5 \\
Post-Tiva Canyon pre-Rainier Mesa rhyolites ${ }^{2}$ & \\
Paintbrush Group & 12.7 \\
Tiva Canyon Tuff & -- \\
Yucca Mountain Tuff & -- \\
Pah Canyon Tuff & 12.8 \\
Topopah Spring Tuff & 12.9 \\
Calico Hills Formation & \\
Crater Flat Group & - \\
Prow Pass Tuff & 13.25 \\
Bullfrog Tuff & -- \\
Tram Tuff & 14.0 \\
\hline Lithic Ridge Tuff & \\
\hline
\end{tabular}

${ }^{\mathrm{l}}$ Ages have not been determined for all units.

${ }^{2}$ This informal grouping represents multiple rhyolites of small areal extent enupted from multiple sources at the margins of calderas such as the Timber Mountain caldera complex north of Yucca Mountain. Correlations are incompletely understood for all such identified rhyolites and calderas.

Many studies (summarized in Volume 1, Part A, of the SCP for Yucca Mountain; U.S. Department of Energy, 1988, section 1.3) have shown that the tectonic setting of Yucca Mountain is complex, with the area situated within the Basin and Range physiographic province near the intersection of the northwest-trending Walker Lane and the northeasttrending Spotted Range-Mine Mountain structural zone (for discussion, see Carr, 1984). The
Walker Lane is a major structural lineament and appears to be a zone of transition between an area to the north and east characterized by dip-slip (normal) faulting, and an area to the south and west characterized by both dip-slip and right-lateral strike-slip faulting. Well-exposed low-angle detachment faults have been documented in regions that surround Yucca Mountain (Hamilton, 1988; Maldonado, 1990; Scott, 1990; Simonds and others, 1996; and Hoisch and others, 1997). Those detachment faults and the closely spaced high-angle faults at Yucca Mountain led some investigators to propose detachment(s) beneath Crater Flat and Yucca Mountain (Hamilton, 1988; Spengler and Fox, 1989; and Scott, 1990), but recent geophysical results are inconclusive on this issue (Brocher and others, 1996; Majer and others, 1996).

\section{GEODETIC LEVELING}

Determination of contemporary motion on geologic structures requires establishment of a network of level lines from which to determine movement. An existing first-order level line extends from a point on U.S. Highway 95 (benchmark location S16, fig. 3) north-northeast across Crater Flat, east over Yucca Mountain, southeast across Jackass Flats and between Skull and Little Skull Mountains, across Rock Valley and ends back on Highway 95 (benchmark location I17, fig. 3). This 92-km-long line, first established and surveyed during 1956-59, was designed to cross the Rock Valley fault and the major structural blocks and block-bounding faults of Yucca Mountain. It contains 133 benchmarks, one per kilometer except for a $20-\mathrm{km}$ interval across Yucca Mountain, where spacing shortens to about $0.5 \mathrm{~km}$. Since 1983, the line has been resurveyed every 1 or 2 years $(1983,1983-84,1985-86,1988,1990-91$, and 1992-93); recordings are contained in unpublished geodetic leveling reports by $\mathrm{T}$. K. Bray (U.S. Geological Survey, written commun., 1993), G. C. Perasso (U. S. Geological Survey, written commun., 1993), and E. I. Balazs (National Geodetic Survey, written commun., 1993). Survey observations made after 1984 meet first-order Class 1 standards established by the Federal Geodetic Control Committee (1984), and the 1990-91 and 1992-93 series were double-run surveys.

A preliminary analysis of the level-line survey data was made primarily to examine possible effects 


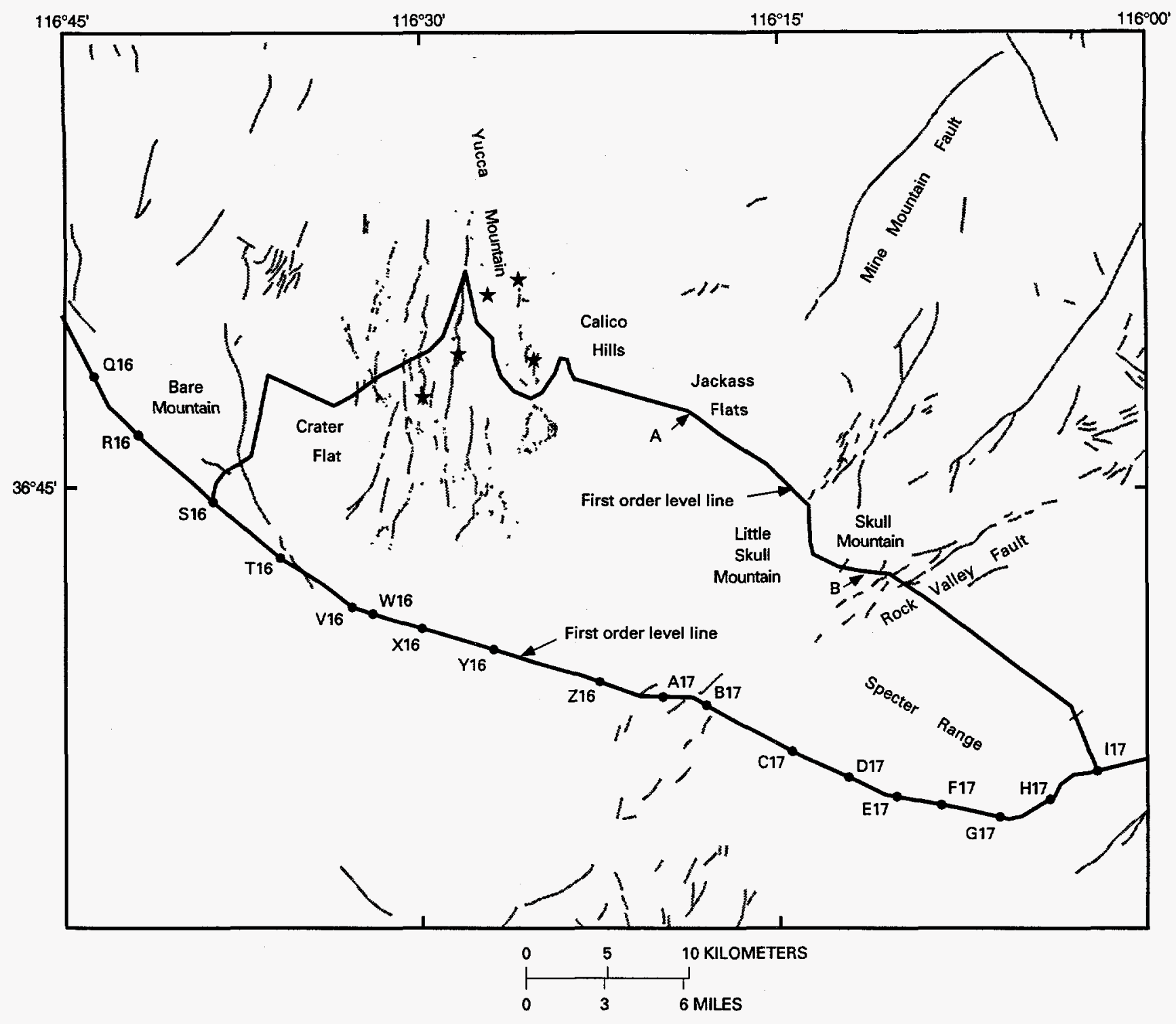

Figure 3. Index map showing location of first-order level lines in the vicinity of Yucca Mountain, Nevada. Points A and B are in reference to figure 4, and benchmark locations (for example, W16) are in reference to figure 5. Faults shown are modified from Piety (1996) and Simonds and others (1995). Stars show locations of quadrilaterals across major faults at Yucca Mountain. 
of the June 29, 1992, Little Skull Mountain earthquake (M 5.8) and also to determine whether there had been any noticeable change in benchmark elevations across Yucca Mountain during 1983-93. The analysis consisted of a comparison of the pre- and postearthquake benchmark elevations by (1) subtracting the post-earthquake elevations from the preearthquake elevations, and (2) plotting the elevation differences with respect to a reference line that represented values recorded during the 1985-86 survey (K.S. Koepsell, National Geodetic Survey, written commun., 1996). The results are shown in figure 4. Based principally on data from the 1983 , 1985-86, 1988, and 1992-93 surveys, the most noticeable observation to be made is that the preearthquake benchmark elevations in the vicinity of Little Skull Mountain were higher than the postearthquake elevations (fig. 4). The negative elevation changes recorded in the $1992-93$ survey occur in an area that lies between 53 and $70 \mathrm{~km}$ east of the west end of the level line (points A and B in fig. 3), with the maximum change of $22 \mathrm{~mm}$ observed at a distance of about $62 \mathrm{~km}$, which is $2 \mathrm{~km}$ northwest of Little Skull Mountain. The downdropped area coincides closely with an area that lies between the southwestward projection of the Mine Mountain fault in Jackass Flats and the Rock Valley fault in Rock Valley (fig. 3).

The observed decrease in benchmark elevations in the vicinity of Little Skull Mountain is in close agreement with the interpretation of K.D. Smith and others (University of Nevada/Reno, written commun., 1995) who described the main shock of the Little Skull Mountain earthquake as involving primarily down-tothe-southeast dip-slip movement on a steeply dipping, northeast-striking fault plane. Meremonte and others (1995) reported that (1) a projection of the mainshock fault plane to the surface, delineated by its focal mechanism and distribution of aftershocks, defines a strike subparallel to a north-northeast structural trend within Jackass Flats and collinear with the Mine Mountain fault system; and (2) the mainshock focal mechanism and the aftershock distribution indicate a normal-slip rupture. Savage and others (1994) also found that normal slip provided a close fit to the resulting deformation observed in a $50-\mathrm{km}$-aperture trilateration network centered on Yucca Mountain (see discussion below). It is interesting to note that the Eureka Valley earthquake (M 6.1) that occurred May 17,1993 , on the border between California and Nevada resulted in a depression similar in width and depth to that created by the Little Skull Mountain event (Peltzer and Rosen, 1995).

The correlation of elevation change with topography indicates that there may have been elevation-dependent errors along some sections of the level line, thus calling into question whether or not actual deformation is being recorded. This relation is most apparent across Yucca Mountain (from 25 to $35 \mathrm{~km}$ ), particularly in the elevations recorded during the $1983,1983-84$, and 1988 surveys. Also noticeable, but less apparent, is the correlation of elevation change with topography toward the southeastern end of the survey line ( 75 to about $95 \mathrm{~km}$ ). The pronounced deviations of the recordings made during the 1983-84 and 1990-91 surveys from the more consistent values obtained in the other surveys suggest that further processing and analysis are required to determine the cause(s) of the deviations and the overall validity of the survey results.

Level-line surveys also have been conducted along Highway 95 between Beatty and Las Vegas, beginning with a third-order leveling survey by the U.S. Geological Survey in 1907, followed by firstorder surveys by the National Geodetic Survey in 1915 and again during the $1980-84$ period. The accumulated geodetic data have been compiled by Gilmore (1992), with special attention given to changes in elevation at bench-mark locations spaced 1.5 to $6 \mathrm{~km}$ apart on that part of Highway 95 that is between the western and eastern ends of the level line across Yucca Mountain (fig. 3). By using the 1907 survey as a baseline, the 1915 and 1980-84 data show negative height changes ranging from 3 to $13 \mathrm{~cm}$ for an area south of Bare Mountain and Crater Flat (between bench marks Q16 and V16, figs. 3 and 5), which is referred to as the Crater Flat/Yucca Mountain structural depression by Gilmore (1992). The Bare Mountain fault zone coincides with the largest of these negative height changes. Eastward from bench mark W16 (fig. 3), positive height changes of 5 to $8 \mathrm{~cm}$ were recorded along a portion of the level line that is located directly south of mapped segments of several of the north-striking normal faults at and near Yucca Mountain (fig. 5). Height changes increase still farther eastward across the southwestward projection of the Rock Valley fault zone, leveling off to a relative uplift of 15 to $20 \mathrm{~cm}$ over the broad region between that point and the Las Vegas area. In general, the 1980-84 survey shows negative height changes with respect to the 1915 survey. 

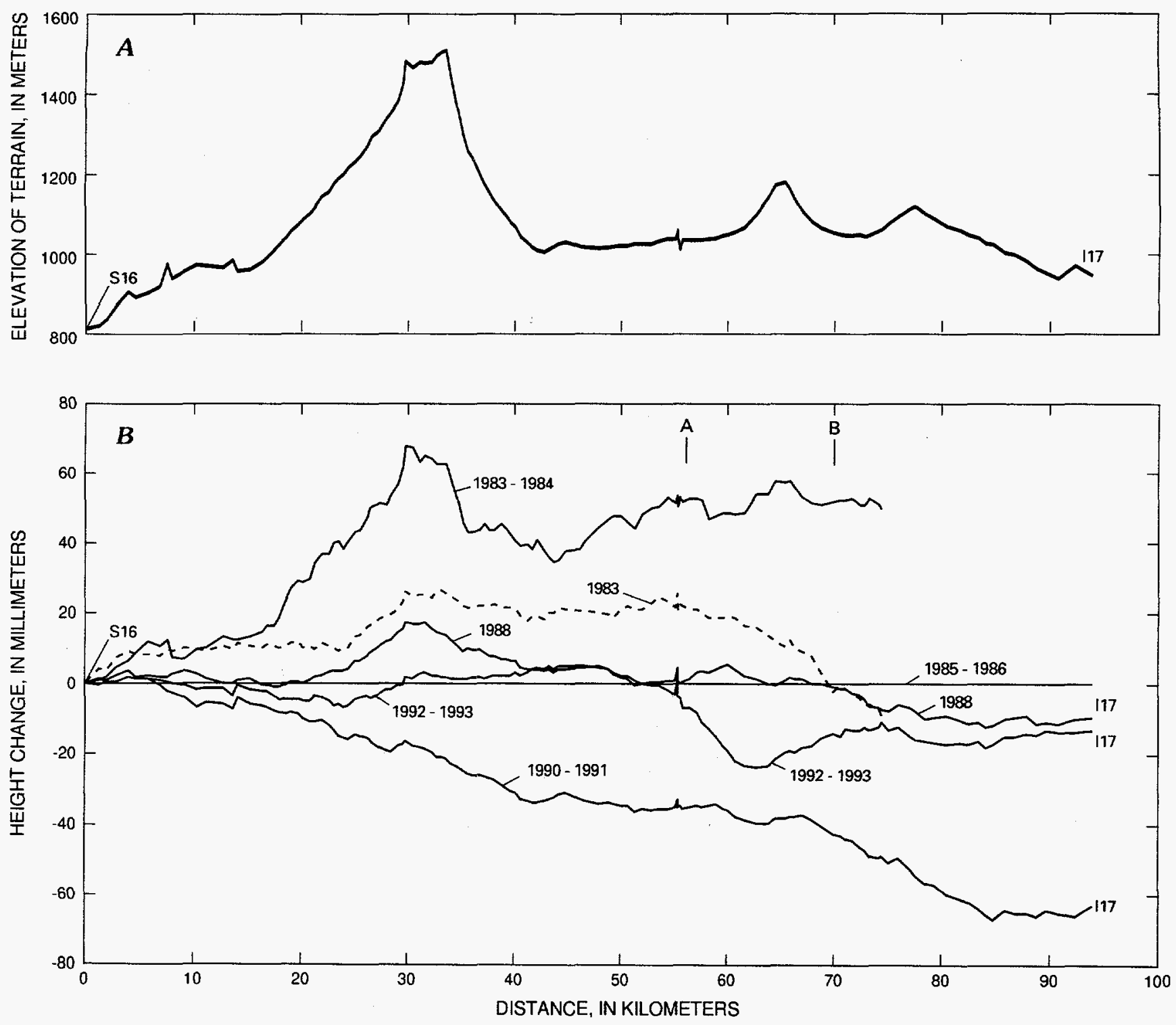

Figure 4. A., Profile plot showing data from surveys of level line across Yucca Mountain, Nevada, during the period 1983-1993 (after K.S. Koepsell, National Geodetic Survey, written commun., 1996); B., Data from the 1985-1986 survey are used as the baseline to show changes in elevation. Location of level line points $A$ and $B$ are shown on figure 3 . 

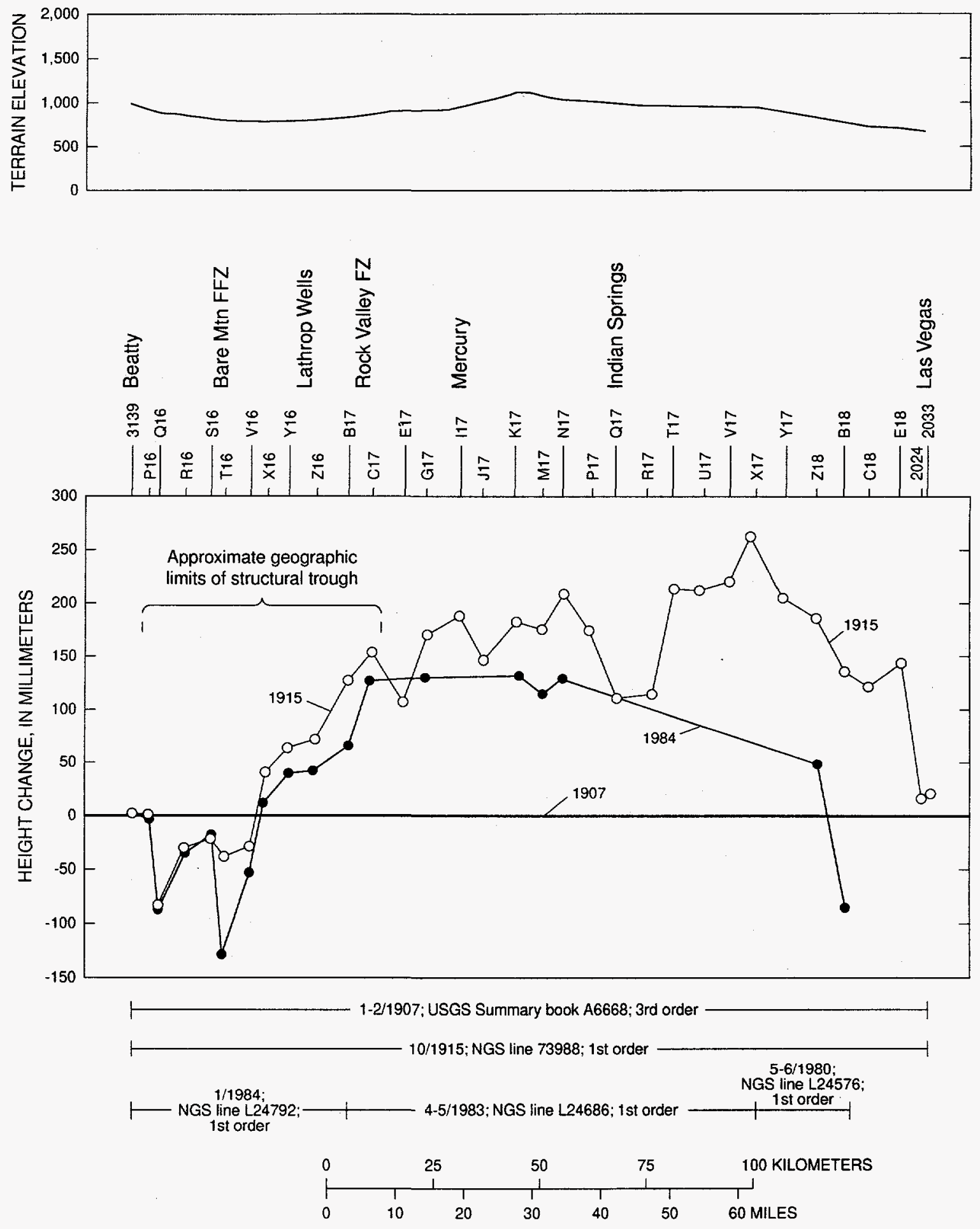

Figure 5. Profiles showing terrain elevations and height changes with respect to the 1907 baseline between Beatty and Las Vegas, Nevada (from Gilmore, 1992). Locations of bençh marks Q16 eastward to 117 are shown on figure 3 . 
Quadrilateral networks, consisting of four corner stations a few hundred to several hundred meters apart and arranged in near-rectangular patterns, were established across several of the major normal faults at Yucca Mountain in the early 1980s (fig. 3). The distances between the stations and their elevations were measured in 1983, 1983-84, 1984, 1985-86, and 1988 with surface-based surveying instruments.

During this 5-year period, no changes in either the horizontal or vertical positions of the stations in any of the quadrilaterals were detected that could be interpreted as providing clear evidence of recent fault movement (J.M. Vukovich, U.S. Geological Survey, oral commun., 1996). Beginning in the early 1990s, the quadrilaterals were resurveyed using Global Positioning System (GPS) methods; GPS surveys over a period of several more years are needed before meaningful results can be obtained because the rate of movement, if there is any, is so small that it cannot be identified over a short period of time within the limits of error of the methods involved.

\section{TRILATERATION - GLOBAL POSITIONING SYSTEM}

Deformation within a 50-km-aperture trilateration network in the Yucca Mountain area has been periodically measured by the U.S. Geological Survey during 1983-93 (Savage and others, 1994; see fig. 6). The network was surveyed in 1983 and 1984 by measuring distances between stations with a geodolite, whereas in 1993 the distances were surveyed using GPS, and some were measured with both geodolite and GPS to provide data for correcting differences between the two methods. The resulting survey data were interpreted by Savage and others (1994) to indicate that no significant deformation was detected across the trilateration network for this 10 -year period, except for coseismic deformation associated with the June 29, 1992, Little Skull Mountain earthquake in the southeastern corner of the network (fig. 6). Using a fault plane determined from seismic data (dip $54^{\circ} \mathrm{SE}$, strike $\mathrm{N} 35^{\circ} \mathrm{E}$ ), Savage and others (1994) determined that $0.580 \pm 0.075 \mathrm{~m}$ of normal slip on a $5-\mathrm{km}^{2}$ rupture surface at a depth of about $8 \mathrm{~km}$ provided a close fit to the observed deformation in that part of the network.

Horizontal and vertical changes in the positions of about 20 stations are being recorded by GPS methods along a $140-\mathrm{km}$-long profile that stretches from Beatty, Nevada, southwest to Coso Junction, California. This line spans several major structural features, including the Furnace Creek fault zone, Death Valley, the Panamint Mountains, the Panamint Valley fault zone, and prominent faults near Coso Junction. Results of these surveys are not yet available.

A regional network of GPS stations was established jointly by the Nuclear Regulatory Commission, California Institute of Technology, and the Smithsonian Institute in 1991 (Southwest Research Institute, 1995). The network consists of 15 survey sites in 3 subnetworks: Yucca Mountain - 5 sites to measure strain across the Bare Mountain fault zone, Crater Flat, Yucca Mountain proper, and Jackass Flats; Death Valley -4 sites to determine the rate of strain accumulation across the Northern Death ValleyFurnace Creek fault zone, plus 2 additional sites in the central part of Death Valley to provide control for determining strains across the Death Valley-Furnace Creek and Hunter Mountain-Panamint fault zones at positions south of the Death Valley and Hunter Mountain subnets; and Hunter Mountain - 4 sites for measuring strain across the Hunter Mountain fault (see fig. 7 for fault locations). Preliminary results of GPS surveys conducted in 1991, 1993, and 1994 indicate two important trends in relation to contemporary strain patterns in the Yucca Mountain region, including (1) vertical and horizontal motions around the potential radioactive waste repository site may be present and would be detectable with further monitoring; and (2) significant horizontal (as much as $5 \mathrm{~mm} / \mathrm{yr}$ ) and vertical (as much as $20 \mathrm{~mm} / \mathrm{yr}$ ) strains are indicated along major fault zones within 50 to $100 \mathrm{~km}$ of Yucca Mountain, but accumulated motions are barely measurable by the 1991-94 surveys (Southwest Research Institute, 1995). There is uncertainty regarding strain rates because of the short period of time represented by these surveys. Continued monitoring of the network, however, should bring improvement in these uncertainties.

\section{VERY LONG BASELINE INTERFEROMETRY}

Very Long Baseline Interferometry (VLBI) is a relatively new geodetic technique that allows measurements of the directions and rates of change of position of stations that are typically separated by 


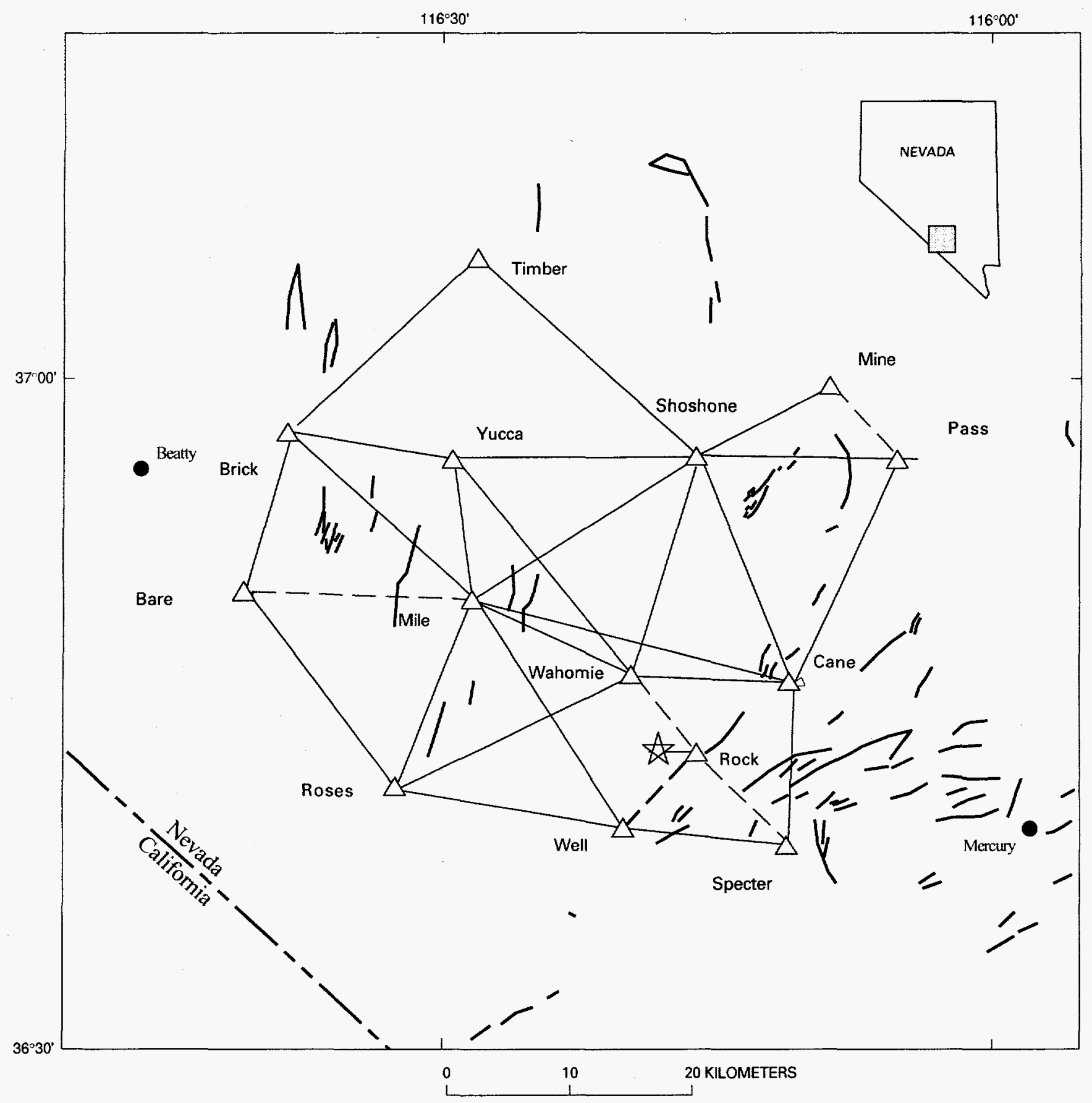

Figure 6. Trilateration network near Yucca Mountain, Nevada. Lines show the measured distances; solid lines were measured in all three surveys, but dashed lines were included in only one of the 1983 and 1984 surveys. The star is the epicenter of the 1992 Little Skull Mountain earthquake. The potentialYucca Mounain waste disposal site is at station Mile. Sinuous lines represent faults. (Modified from Savage and others, 1994). 


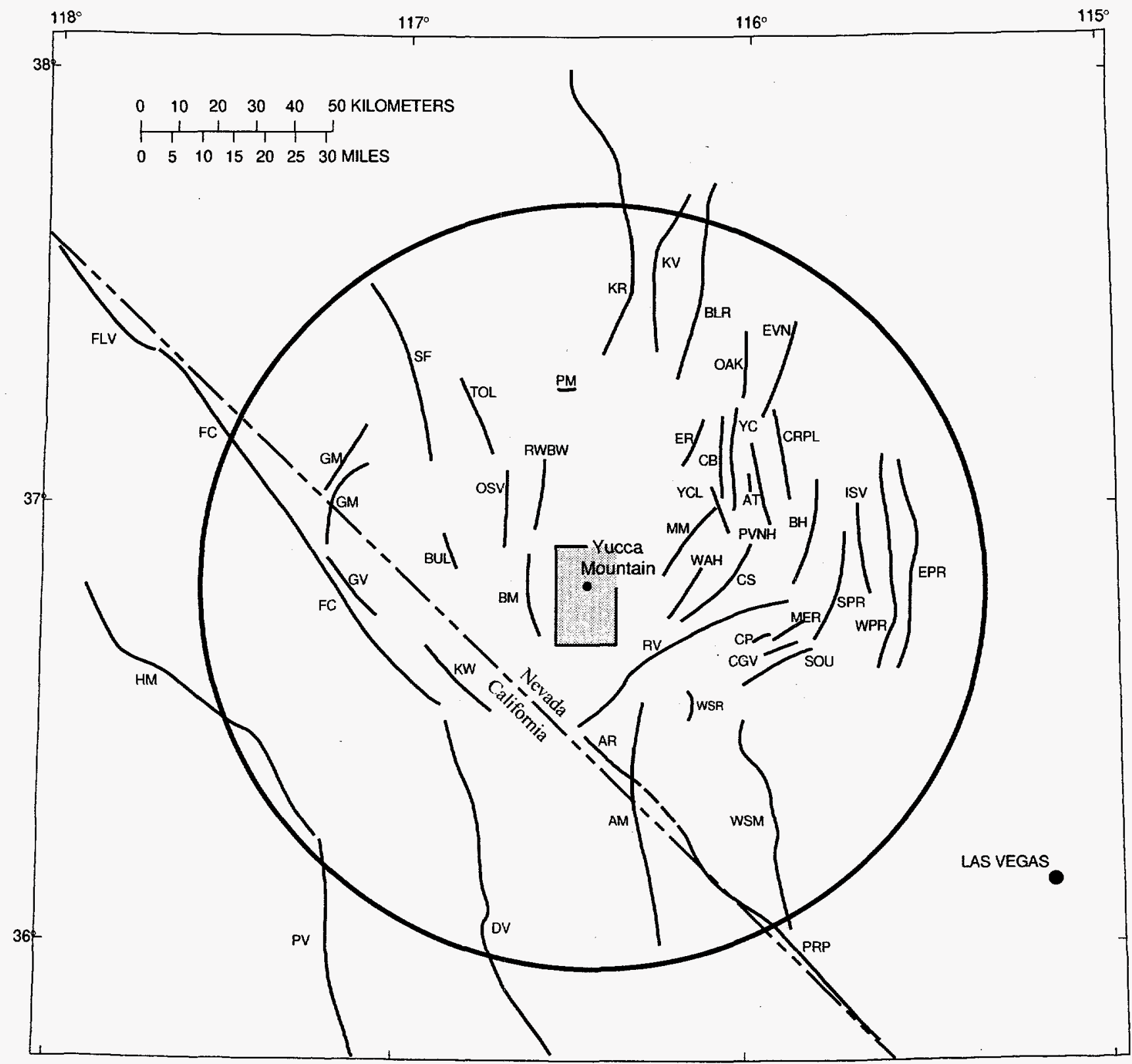

\begin{tabular}{|c|c|c|c|c|c|c|c|}
\hline \multicolumn{8}{|c|}{ Abbreviations of faults } \\
\hline AM & Ash Meadows & CS & Cane Spring & KR & Kawich Range & RV & Rock Valley \\
\hline AR & Amargosa River & DV & Death Valley & KV & Kawich Valley & RWBW & Rocket Wash-Beatty \\
\hline AT & Area Three & EPR & East Pintwater Range & $\mathrm{KW}$ & Keane Wonder & & Wash \\
\hline $\mathrm{BH}$ & Buried Hills & ER & Eleana Range & MER & Mercury Ridge & SF & Sarcobatus Flat \\
\hline BLR & Belted Range & EVN & Enigrant Valley North & MM & Mine Mountain & SOU & South Ridge \\
\hline $\mathrm{BM}$ & Bare Mountain & FC & Furnace Creek & OAK & Oak Spring Butte & SPR & Spotted Range \\
\hline BUL & Bullfrog Hills & FLV & Fish Lake Valley & OSV & Oasis Valley & TOL & Tolicha Peak \\
\hline $\mathrm{CB}$ & Carpetbag & GM & Grapevine Mountains & PM & Paliute Mesa & WAH & Wahmonie \\
\hline CGV & Crossgrain Valley & GV & Grapevine & PRP & Pahrump & WPR & West Pintwater Range \\
\hline $\mathrm{CP}$ & Checkpoint Pass & HM & Hunter Mountain & PV & Panamint Valley & WSM & West Springs Mountain \\
\hline CRPL & $\begin{array}{c}\text { Cockeyed Ridge- } \\
\text { Papoose Lake }\end{array}$ & ISV & Indian Springs Valley & PVNH & $\begin{array}{l}\text { Plutonium Valley- } \\
\text { N Halfpint Range }\end{array}$ & $\begin{array}{l}\text { WSR } \\
\text { YC } \\
\text { YCL }\end{array}$ & $\begin{array}{l}\text { West Specter Range } \\
\text { Yucca } \\
\text { Yucca Lake }\end{array}$ \\
\hline
\end{tabular}

Figure 7. Index map showing location of relevant and potentially relevant faults capable of generating average median and $84^{\text {th }}$-percentile peak accelerations that equal or exceed $0.1 \mathrm{~g}$ at the potential waste repository at Yucca Mountain, Nevada. The large circle is $100 \mathrm{~km}$ in radius from the site. To preserve the sense of the number of faults in the region, this index figure shows many faults not mentioned in the text. 
$200 \mathrm{~km}$ or more. Thus, VLBI data provide a picture of deformation over scales of several hundred kilometers, even distances as long as across the entire Basin and Range Province, but observations are temporally limited to slightly more than the last decade. VLBI data from across the western United States have been interpreted to indicate that, overall, the Basin and Range is deforming at rates between 8 and $13 \mathrm{~mm} / \mathrm{yr}$, in a northwesterly direction (N30 $\mathrm{W}$ to $45^{\circ} \mathrm{W}$ ), relative to stations on and near the Colorado Plateau (Sauber, 1989; DeMets and others, 1987, 1990; Ward, 1990; Argus and Gordon, 1991; Dixon and others, 1995). Dixon and others (1995) suggested that this motion can be resolved into $5 \mathrm{~mm} / \mathrm{yr}$ east-west extension (presumably on the Wasatch fault) east of Ely, Nevada, and about $10 \mathrm{~mm} / \mathrm{yr}$ northward motion of the Sierra Nevada with respect to Ely. Geologic, smaller scale geodetic, and seismicity studies indicate that three zones along the western edge of the southern Great Basin - the Owens Valley, Panamint ValleyHunter Mountain, and Death Valley-Furnace CreekFish Lake Valley fault zones - accommodate most of the deformation that extends northward from the Mojave Desert along what has been referred to as the Eastern California Shear Zone (Dokka and Travis, 1990; Savage and others, 1990; Richard, 1992; Dixon and others, 1995; Reheis and Dixon, 1996). Based on combined geologic and geodetic studies in the Death Valley region, Reheis and Dixon (1996) suggested that several of the major northwest-striking fault zones are connected by short north-striking normal faults that transfer slip among the major faults via right steps. At present, the total slip rate of $10.7 \pm 1.6 \mathrm{~mm} / \mathrm{yr}$ (Dixon and others, 1995) across the shear zone near latitude $36^{\circ} 15^{\prime}$ is distributed among the Owens Valley fault zone, the Hunter Mountain-Panamint Valley faults, and the Furnace Creek fault zone, but northward the slip is increasingly transferred eastward to the Fish Lake Valley fault zone (Reheis and Dixon, 1996). The eastern limit of the Eastern California Shear Zone is recognized to be the Death Valley, Furnace Creek, and Fish Lake Valley fault zones, which are located approximately $50 \mathrm{~km}$ west-southwest of Yucca Mountain at their closest proximity (see fig. 7 for fault locations).

\section{CONCLUSIONS}

The geodetic surveys show no changes in elevation that can confidently be attributed to fault movements at and near Yucca Mountain, except in response to the June 29, 1992, Little Skull Mountain earthquake. In that case, both the resurveys of the level line in the vicinity of Little Skull Mountain and the measurements obtained from a trilateration network that spans the Yucca Mountain area are in agreement with the amount and type of motion deduced from seismic records. Regional geodetic surveys show that strain and large slip rates exist within 50 to $100 \mathrm{~km}$ west of Yucca Mountain, but the motions are only barely resolvable by GPS methods and the current temporally limited data sets.

\section{REFERENCES}

Argus, D.F., and Gordon, R.G., 1991, Current Sierra Nevada-North America motion from very long baseline interferometry -implications for the kinematics of the western United States: Geology, v. 19, p. $1085-1088$.

Brocher, T.M., Hart, P.E., Hunter, W. Clay, and Langenheim, V.E., 1996, Hybrid-source seismic reflection profiling across Yucca Mountain, Nevada: Regional lines 2 and 3: U.S. Geological Survey Open-File Report 96-28, 110 p.

Buesch, D.C., Spengler, R.W., Moyer, T.C., and Geslin, J.K., 1996, Revised stratigraphic nomenclature and macroscopic identification of lithostratigraphic units of the Paintbrush Group exposed at Yucca Mountain, Nevada: U.S. Geological Survey Open-File Report 94-469, $47 \mathrm{p}$.

Byers, F.M., Jr., Carr, W.J., Orkild, P.P., Quinlivan, W.D., and Sargent, K.A., 1976, Volcanic suites and related cauldrons of Timber Mountain-Oasis Valley caldera complex, southern Nevada: U.S. Geological Survey Professional Paper 919, $70 \mathrm{p}$.

Carr, M.D., and Monsen, S.A., 1988, A field trip guide to the geology of Bare Mountain, in Weide, D.L., and Faber, M.L., eds., This extended land, geological journeys in the southern Basin and Range: Geological Society of America, Cordilleran Section, Field Trip Guidebook, p. 50-57.

Carr, W.J., 1984, Regional structural setting of Yucca Mountain, southwestern Nevada; and Late Cenozoic rates of tectonic activity in parts of the southwestern Great Basin, Nevada and California: U.S. Geological Survey Open-File Report 84-854, 109 p. 
Carr, W.J., Byers, F.M., Jr., and Orkild, P.P., 1986, Stratigraphic and volcano-tectonic relations of the Crater Flat Tuff and some older volcanic units: U.S. Geological Survey Professional Paper 1323, 28 p.

Christiansen, R.L., and Lipman, P.W., 1965, Geologic map of the Topopah Spring NW quadrangle, Nye County, Nevada: U.S. Geological Survey Geological Quadrangle Map GQ-444, scale 1:24,000.

DeMets, C., Gordon, R.G., Stein, S., and Argus, D.F., 1987, A revised estimate of Pacific-North America motion and implications for western North American plate boundary zone tectonics: Geophysical Research Letters, v. 14, p. $911-914$.

DeMets, C., Gordon, R.G., Argus, D.F., and Stein, S., 1990, Current plate motions: Geophys. J. Int., v. 101, p. 425-278.

Dixon, T.H., Robaudo, S., Lee, J., and Reheis, M.C., 1995, Constraints on present day Basin and Range deformation from space geodesy: Tectonics, v. 14, p. 755-772.

Dokka, R.K., and Travis, C.J., 1990, Late Cenozoic strikeslip faulting in the Mojave Desert, California: Tectonics, v. 9, p. 311-340.

Federal Geodetic Control Committee, 1984, Standards and specifications for geodetic control networks: National Oceanic and Atmospheric Administration, Rockville, Maryland, $28 \mathrm{p}$.

Fridrich, C.J., in press, Tectonic evolution of Crater Flat basin, Yucca Mountain region, Nevada, in Wright, L., and Troxel, B., eds., Geological Society of America Special Paper, Cenozoic basins of the Death Valley region.

Gilmore, T.D., 1992, Geodetic leveling data used to define historical height changes between Tonopah Junction and Las Vegas, Nevada: U.S. Geological Survey OpenFile Report 92-450, 11 p.

Hamilton, W., 1988, Detachment faulting in the Death Valley region, California and Nevada, in Carr, M.D., and Yount, J.C., eds., Geologic and hydrologic investigations of a potential nuclear waste disposal site at Yucca Mountain, southern Nevada: U.S. Geological Survey Bulletin 1790, p. 51-86.

Hoisch, T.D., Heisler, M.T., and Zartman, R.E., 1997, Timing of detachment faulting in the Bullfrog Hills and Bare Mountain area, southwest Nevada: Inferences from ${ }^{40} \mathrm{Ar} /{ }^{39} \mathrm{Ar}, \mathrm{K}-\mathrm{Ar}, \mathrm{U}-\mathrm{Pb}$, and fission track thermochronology: Journal of Geophysical Research, v. 102, p. 2815-2834.

Majer, E., Feighner, M., Johnson, L., Daley, T., Karageorgi, E., Lee, K.H., Kaelin, B., Williams, K., and McEvilly, T., 1996, Synthesis of borehole and surface geophysical studies at Yucca Mountain, Nevada, and vicinity: Volume I, Surface Geophysics: Berkeley, California, Lawrence Berkeley National Laboratory Report UCID-39319, pagination unknown.
Maldonado, F., 1990, Structural geology of the upper plate of the Bullfrog Hills detachment fault system, southern Nevada: Geological Society of America Bulletin, v. 102 , p. $992-1006$.

Meremonte, M., Gomber, J., and Cranswick, E., 1995, Constraints on the 29 June 1992 Little Skull Mountain, Nevada, earthquake sequence provided by robust hypocenter estimates: Seismological Society of America Bulletin, v. 85, p. 1039-1049.

Peltzer, G., and Rosen, P., 1995, Surface displacement of the 17 May 1993 Eureka Valley, California, earthquake observed by SAR interferometry: Science, v. 268 , p. 1333-1336.

Piety, L.A., 1996, Compilation of known or suspected Quaternary faults within $100 \mathrm{~km}$ of Yucca Mountain, Nevada and California: U.S. Geological Survey OpenFile Report p. 94-112, 404 p.

Rautman, C.A., Whittet, B.C., and South, D.L., 1987, Definitions of reference boundaries for the proposed geologic repository at Yucca Mountain, Nevada: Sandia National Laboratory SAND86-2157, 48 p.

Reheis, M.C., and Dixon, T.H., 1996, Kinematics of the Eastern California shear zone: evidence for slip transfer from Owens Valley and Saline Valley fault zones to Fish Lake Valley fault zone: Geology, v. 24, no. 4, p. 339-342.

Richard, S.M., (ed.), 1992, Deformation associated with the Neogene Eastern California Shear Zone, southeastern California and southwestern Arizona: Proceedings of the Workshop on the Eastern California Shear Zone, San Bernardino County Museums Special Publication 92-1, Redlands, California, $78 \mathrm{p}$.

Sauber, J., 1989, Geodetic measurement of deformation in California: NASA Technical Memoir 100732, 211 p.

Savage, J.C., Lisowski, M., and Prescott, W.H., 1990, An apparent shear zone trending north-northwest across the Mojave Desert into Owens Valley, eastern California: Geophysical Research Letters, v. 17, p. 2113-2116.

Savage, J.C., Lisowski, M., Gross, W.K., King, N.E., and Svarc, J.L., 1994, Strain accumulation near Yucca Mountain, Nevada, 1983-1993: Journal of Geophysical Research, v. 99, p. 18103-18107.

Sawyer, D.A., Fleck, R.J., Lanphere, M.A., Warren, R.G., Broxton, D.E., and Hudson, M.R., 1994, Episodic caldera volcanism in the Miocene southwestern Nevada volcanic field - revised stratigraphic framework, ${ }^{40} \mathrm{Ar} /{ }^{39} \mathrm{Ar}$ geochronology, and implications for magmatism and extension: Geological Society of America Bulletin, v. 106, p. 1304-1318.

Scott, R.B., 1990, Tectonic setting of Yucca Mountain, southwest Nevada, in Wernicke, B.P., ed., Basin and Range extensional tectonics near the latitude of Las 
Vegas, Nevada: Geological Society of America Memoir 176, p. 251-282.

Scott, R.B., and Bonk, Jerry, 1984, Preliminary geologic map of Yucca Mountain, Nye County, Nevada, with geologic sections: U.S. Geological Survey Open-File Report 84-494, scale 1:12,000.

Simonds, F.W., Whitney, J.W., Fox, K.F., Jr., Ramelli, A., Yount, J., Carr, M.D., Menges, C.M., Dickerson, R., and Scott, R.B., 1995, Map of fault activity in the Yucca Mountain area, Nye County, Nevada:

U.S. Geological Survey Miscellaneous Investigations Map I-2520, scale 1:24,000.

Simonds, F.W., Fridrich, C.J., Hoisch, T.D., and Hamilton, W.B., 1996, A synthesis of detachment fault studies in the Yucca Mountain region: FOCUS '95, Proceedings of the Topical Meeting on Methods of Seismic Hazards Evaluation, American Nuclear Society, Inc., LaGrange Park, Illinois, p. 107-114.

Snyder, D.B., and Carr, W.J., 1984, Interpretation of gravity data in a complex volcano-tectonic setting, southwestern Nevada: Journal of Geophysical Research, v. 89, p. 10193-10206.

Southwest Research Institute, 1995, Faulting in the Yucca Mountain region: Critical review and analyses of tectonic data from the central Basin and Range: Southwest Research Institute, Center for Nuclear Waste Regulatory Analyses, CNWRA 95-017, 14 p.

Spengler, R.W., and Fox, K.F., Jr., 1989, Stratigraphic and structural framework of Yucca Mountain, Nevada: Radioactive Waste Management and the Nuclear Fuel Cycle, v. 13(1-4), p. 21-36.

United States Department of Energy, 1988, Site characterization plan, Yucca Mountain site, Nevada Research and Development Area, Nevada: U.S. Department of Energy, Office of Civilian Radioactive Waste Management DOE/RW0199, 8 volumes.

Ward, S.N., 1990, Pacific-North America plate motions-New results from very long baseline interferometry: Journal of Geophysical Research, v. 95 , p. $21965-21981$. 